\title{
Effect of cross-linked biodegradable polymers on sustained release of sodium diclofenac-loaded microspheres
}

\author{
Avik Kumar Saha ${ }^{1}$, Sarbani Dey Ray, ${ }^{1, *}$ \\ Department of Pharmaceutics, Dr. B.C. Roy College of Pharmacy and Allied Health Sciences, \\ Durgapur, West Bengal, India
}

\begin{abstract}
The objective of this study was to formulate an oral sustained release delivery system of sodium diclofenac(DS) based on sodium alginate (SA) as a hydrophilic carrier in combination with chitosan (CH) and sodium carboxymethyl cellulose (SCMC) as drug release modifiers to overcome the drug-related adverse effects and to improve bioavailability. Microspheres of DS were prepared using an easy method of ionotropic gelation. The prepared beads were evaluated for mean particle size, entrapment efficiency, swelling capacity, erosion and in-vitro drug release. They were also subjected to various studies such as Fourier Transform Infra-Red Spectroscopy (FTIR) for drug polymer compatibility, Scanning Electron Microscopy for surface morphology, X-ray Powder Diffraction Analysis (XRD) and Differential Scanning Calorimetric Analysis (DSC) to determine the physical state of the drug in the beads. The addition of SCMC during the preparation of polymeric beads resulted in lower drug loading and prolonged release of the DS. The release profile of batches F5 and F6 showed a maximum drug release of $96.97 \pm 0.356 \%$ after $8 \mathrm{~h}$, in which drug polymer ratio was decreased. The microspheres of sodium diclofenac with the polymers were formulated successfully. Analysis of the release profiles showed that the data corresponds to the diffusion-controlled mechanism as suggested by Higuchi.
\end{abstract}

Uniterms: Alginate beads/preparation. Alginate beads/evaluation. Drugs/sustained release. Interpenetrating network. Sodium diclofenac/microsphere/sustained release. Ionotropic gelation.

O objetivo deste estudo foi elaborar um sistema de entrega de oral de liberação sustentada de diclofenaco sódico (DS) com base em alginato de sódio (SA), como um transportador hidrofílico em combinação com quitosana $(\mathrm{CH})$ e carboximetilcelulose de sódio (SCMC) como modificadores de liberação de fármaco para diminuir os efeitos adversos e melhorar a biodisponibilidade. Prepararam-se microesferas de DS usando um método fácil de geleificação ionotrópica. Avaliaram-se os grânulos preparados quanto ao tamanho médio de partícula, eficiência de compressão, inchaço in vitro, erosão e capacidade de liberação de fármacos. Estes tammbém foram submetidos a vários estudos, como espectrometria no infravermelho com transformada de Fourier (FTIR) para compatibilidade de fármaco e polímero, microscopia eletrônica de varredura para morfologia de superfície, análise de difração de raios-X (XRD) do pós e análise calorimétrica diferencial de varredura (DSC) para determinar o estado físico do fármaco nos grânulos. A adição de SCMC durante a preparação de grânulos do polímero resultou em fármacos com menor carga de fármaco e liberação prolongada do DS. O perfil de liberação dos lotes F5 e F6 apresentou máximo de fármaco liberado de $96,97 \pm 0,356 \%$ após 8 h após o que a proporção do fármaco no polímero foi diminuída. As microesferas de diclofenaco de sódio com os polímeros foram formuladas com sucesso. A análise dos perfis de liberação mostrou que os dados correspondem ao mecanismo de difusão controlada, como sugerido por Higuchi.

Unitermos: Grânulos de alginato/preparação. Grânulos de alginato/avaliação. Fármacos/liberação sustentada. Rede de interpenetração. Diclofenaco de sódio/microesferas/liberação sustentada. Geleificação ionotrópica.

\footnotetext{
*Correspondence: B.C. Roy. College of Pharmacy and Allied Health Sciences, Dr. Meghnath saha sarani, Bidhan nagar, Durgapur-12, West Bengal, India. E-mail: sarbanidey_in@yahoo.co.in
} 


\section{INTRODUCTION}

Oral drug delivery using biodegradable natural polymeric particulate systems are becoming a clinical reality with many benefits for patients. The versatility of polymeric materials allows the fabrication of the drug delivery devices with a desirable degree of swelling and consequently of drug release (Basu, Rajendran et al., 2008). Alginate has been used by many researchers for controlled delivery of incorporated materials (Girhepunje et al., 2010; Ouwerx et al., 1998; Bajpai, Sharma, 2004). Alginate is a naturally occurring polysaccharide obtained from marine brown algae. It is composed of linear copolymers of 1 , 4 -linked $\beta$-D mannuronic acid and $\alpha$-L glucuronic acid. It gels in the presence of a divalent cation such as calcium. Microspheres produced using alginate have been used for the encapsulation of a wide variety of bioactive materials, proteins, enzymes, micronutrients, antibodies etc. (Griffith et al., 2000; Rasmussen et al., 2003; Bodmier, Paeratakul, 1989). The bio-adhesive nature of alginate with mucosal membrane helps to achieve intimate contact between intestinal mucosa and lower-sized microspheres (Sezer, Akbuga, 1999; Fernadez-Hervas et al., 1998; GonzalezRodriguez et al., 2002). Chitosan is a cationic linear polysaccharide. It is non-toxic and biodegradable. It is a $\beta(1-4)$ linked biopolymer composed of 2-amino-2-deoxy$\beta$-D-glucan combined by glycosidic linkages. Chitosan consists of a large number of amine groups which allow interaction between chitosan and many other substances. Chitosan exhibits unique functional, nutritional, and biomedical properties (Remunår-López et al., 1998; Kim et al., 2003; Torre et al., 2003). Chitosan has been used for many biomedical and pharmaceutical applications to improve drug delivery as well as for controlled delivery (Sanil et al., 2007; Sipahigil et al., 2006). In the case of drug delivery applications, chitosan has been employed for preparation of drug-loaded microcapsules/ microspheres and used to provide controlled drug release and improve bioavailability of drugs (Lee et al., 1996). Sodium CMC (SCMC) was combined in formulation to improve viscosity and for the additive effect of the mucoadhesive property (Prajapati et al., 2012; Semalty et al., 2008). A concentration range from 0.1 to $0.5 \% \mathrm{w} / \mathrm{v}$ SCMC formed a clear and stable formulation. SCMC was selected as a polymer over other polymers due to its better mucoadhesive capacity in comparison to that of other mucoadhesive polymers such as poly (acrylic acid) (PAA) and polycarbophils. Polyelectrolyte complex (PEC) in the form of beads or microspheres formed by cationic polymer(s) and anionic polymer(s) could further enhance the controlled or prolonged release of the drug. Examples of PEC for controlling drug release include alginate/chitosan (Parfitt, Marindale, 1996), chitosan-cellulose multicore microparticles (Sanil et al.,2007), chitosan-coated pectin (Sipahigil et al., 2006), chitosan/poly(acrylic acid) complexes (Sezer, Akbuga, 1999), poly(vinylalcohol)/sodium alginate blend beads (Gonzålez-Rodriguez et al., 2002), and poly(methacrylic acid-g- ethylene glycol) particles (Lee et al., 1996). The non-steroidal anti-inflammatory drug, sodium diclofenac is a good candidate for the development of oral sustained release formulations. It is administered as conventional tablets/capsules for the treatment of rheumatoid arthritis, osteoarthritis with a dose of 75-150mg divided for administration 2-3 times a day (Parfitt et al., 1996). An adverse gastrointestinal reaction has been observed and due to a short biological half-life it requires multiple dosing. This leads to fluctuation in the drug-blood levels and dose-related adverse effects, and multiple dosing also fails to release the drug in the desired amount at the desired rate which often results in poor patient compliance and inefficient therapy (Peter et al., 1997).

The aim of the present study was to a develop an oral sustained-release delivery system consisting of beads of sodium diclofenac using sodium alginate as a hydrophilic carrier in combination with chitosan and sodium carboxymethyl cellulose as drug release modifiers in various proportions to overcome the drugrelated adverse effect and to improve bioavailability. In the proposed method - ionotropic gelation, which involves the addition of a mixture of drug and polymer(s) dispersion into aqueous solution of calcium chloride solution, gelation occurs instantaneously resulting in the formation of spherical microscale-sized beads with narrow particle size, low porosity and an optimum sustained-release profile in various physiological gastrointestinal conditions (Edith et al., 1999; Manjanua et al., 2009; Martisen et al., 1989).

\section{MATERIAL AND METHOD}

\section{Material}

Sodium diclofenac (DS) IP (gift sample from Blue Cross Laboratories Limited, Mumbai); Sodium alginate (SA) (Sigma, USA) - Medium viscosity grade (250 cps$2 \% \mathrm{w} / \mathrm{v}$ of solution in water); Chitosan $(\mathrm{CH})(85 \%$ degree of deacetylation, molecular weight more than $10^{3} \mathrm{kD}$ ) from India sea foods, Cochin, India); Sodium carboxymethyl cellulose (SCMC)(Loba Chemie, Mumbai, India); Calcium chloride dehydrate (E.Merck, India). All other reagents were of analytical grade. 
TABLE I - Formulation design

\begin{tabular}{|c|c|c|c|c|c|c|}
\hline Sl.no & $\begin{array}{c}\text { sodium } \\
\text { alginate(SA) } \\
(\% \mathrm{w} / \mathrm{v})\end{array}$ & $\begin{array}{l}\text { chitosan } \\
(\% \mathrm{w} / \mathrm{v})\end{array}$ & $\begin{array}{c}\text { sodium } \\
\text { carboxymethyl } \\
\text { cellulose }(\mathrm{SCMC}) \\
(\% \mathrm{w} / \mathrm{v}) \\
\end{array}$ & $\begin{array}{l}\text { calcium chloride } \\
(\% \mathrm{w} / \mathrm{v})\end{array}$ & $\begin{array}{l}\text { Drug: sodium } \\
\text { alginate }\end{array}$ & $\begin{array}{l}\text { Gelation time } \\
\text { (h) }\end{array}$ \\
\hline F1 & 3 & 0 & 0 & 2 & $1: 4$ & 4 \\
\hline F2 & 3 & 0.75 & 0.5 & 2 & $1: 4$ & 4 \\
\hline F3 & 3 & 0.5 & 1 & 2 & $1: 4$ & 4 \\
\hline $\mathrm{F} 4$ & 3 & 0 & 0.5 & 2 & $1: 4$ & 1 \\
\hline F5 & 3 & 0.5 & 0 & 2 & $1: 4$ & 1 \\
\hline F6 & 3 & 0.5 & 0.5 & 2 & $1: 3$ & 4 \\
\hline F7 & 4 & 0.5 & 0.5 & 2 & $1: 2$ & 4 \\
\hline F8 & 3 & 0.75 & 1 & 3 & $1: 4$ & 4 \\
\hline F9 & 3 & 0.5 & 0.5 & 5 & $1: 4$ & 4 \\
\hline
\end{tabular}

\section{Preparation of polyelectrolyte complex microspheres}

The microspheres were prepared using various concentrations of different polymers including sodium alginate, chitosan and sodium carboxymethylcellulose (Table I). The gelation medium was prepared by dissolving Calcium chloride in distilled water at the concentration of $2 \%(\mathrm{w} / \mathrm{v})$. The homogenous mixture of various polymers and drug solution was added drop-wise into the gelation medium using a $10 \mathrm{~mL}$ hypodermic syringe through a \# 21 needle under constant stirring at room temperature. The beads thus formed were cured in the gelation medium for $4 \mathrm{~h}$ and then taken out. The beads thus obtained were immediately put in the sodium alginate solution $(0.1 \% \mathrm{w} / \mathrm{v})$ for $5 \mathrm{~min}$ and then transferred into calcium chloride solution $(1 \% \mathrm{w} / \mathrm{v})$ for $30 \mathrm{~min}$. Finally the beads were taken out, washed with distilled water and then allowed to dry at $30^{\circ} \mathrm{C}$ in a dust-free chamber until they attained constant weight.

\section{Characterization of microspheres}

\section{Particle size analysis and morphological studies}

The particle size determination of sodium alginate beads was carried out using an optical microscope along with ocular and stage micrometer. At least 200 microspheres were analyzed for each preparation and the mean diameter calculated. The surface morphology and appearance of the microspheres were examined by a scanning electron microscopy using a JEOL JSM-6360 model scanning electron microscope (SEM). The beads were mounted on an appropriate stub and then coated with carbon and gold (100 and 50 Á thickness, respectively) sputter module in a vacuum evaporator under an argon atmosphere. The coated samples were then observed under a scanning electron microscope operated at $15 \mathrm{KV}$. Each experiment was done in triplicate.

\section{Determination of entrapment efficiency}

For the determination of drug loading capacity, $100 \mathrm{mg}$ of sodium alginate bead formulation was taken in a $100 \mathrm{~mL}$ volumetric flask and phosphate buffer ( $\mathrm{pH} 7.4)$ was added up to volume and kept overnight. The mixture was then filtered and absorbance measured at $276 \mathrm{~nm}$ using a Cary 50 Bio UV-Visible spectrophotometer. Drug content was computed using a calibration curve prepared using dilutions with concentrations of $1-6 \mu \mathrm{g} / \mathrm{mL}$ of DS. The drug loading capacity of the beads was then computed according to the following equation (Marsh et al., 1967):

$$
\text { Experimental drug loading }=\mathrm{L} / \mathrm{L}_{0} \times 100
$$

where, $\mathrm{L}$ is the actual drug content and $\mathrm{L}_{0}$ is the weighed quantity of beads

Entrapment efficiency was calculated using the formula given below:

$$
\text { Entrapment efficiency }(\%)=\text { EL/TL x } 100
$$

where, EL is the experimental drug loading and TL is the theoretical amount of drug in beads calculated from the quantity added during the fabrication process. Each experiment was done in triplicate.

\section{Swelling Study}

Beads were placed in a watch glass and phosphate 
buffer ( $\mathrm{pH}$ 7.4) was added. Swelling rate was determined by measuring the diameter of several particles periodically. Measurements were made by the sieving method using USP standard sieves (Peter et al., 1997). Each experiment was done in triplicate.

\section{Erosion studies}

The dried beads were weighed and placed in dissolution baskets (Anal et al., 2003). These were then subjected to dissolution in phosphate buffer ( $\mathrm{pH}$ 7.4). The rpm was set at 50. At 1-hr intervals, the beads were taken out from the basket and dried in an oven at $50{ }^{\circ} \mathrm{C}$. When all water was removed, the weight of beads was taken. After this, the beads were placed in the basket again. This process was continued for $6 \mathrm{hr}$. Each experiment was done in triplicate.

These results are given in percentage of bead weight loss (mean \pm SD.; $n=3$ ) using the following formula:

$\% \mathrm{wt} \mathrm{loss}=\frac{\mathrm{W}_{0}-\mathrm{W}_{1}}{\mathrm{~W}_{0}} \times 100$

$w_{o}=$ Initial weight of bead, $w_{l}=$ weight after drying.

\section{In-vitro drug release studies}

In vitro drug release studies were carried out in triplicate using a USP XX II Dissolution test Apparatus (model TDP-06P, Electro Lab, Mumbai, India) at a speed of $50 \mathrm{rpm}$ and the temperature maintained at $37 \pm 0.5{ }^{\circ} \mathrm{C}$. The beads of each formulation were placed in enzyme-free simulated gastric fluid $(900 \mathrm{~mL}, 0.1 \mathrm{~N} \mathrm{HCl} \mathrm{pH} \mathrm{1.2)} \mathrm{for} \mathrm{the}$ first $2 \mathrm{~h}$ then the beads were filtered and again placed in intestinal fluid ( $900 \mathrm{~mL}$, phosphate buffer solution, $\mathrm{pH}$ 7.4) for $7 \mathrm{~h}$. A $5 \mathrm{~mL}$ aliquot of dissolution fluid was withdrawn from the dissolution medium at predetermined time intervals and replaced immediately with the same volume of fresh media. The aliquots were then analyzed for drug content using a Cary 50 Bio UV-Visible spectrophotometer at $276 \mathrm{~nm}$.

\section{Kinetic modeling of drug release}

The dissolution of all the formulations was carried out. The dissolution profile of all the batches was fitted to zero-order, first-order, Higuchi and Korsmeyer-Peppas to ascertain the kinetic modeling of drug release. The reading was then processed for dissolution data using PCP Disso v3 software. Lag time was considered and all the data was processed for fitting of the models.

\section{FTIR Spectroscopic Analysis}

The FT-IR analyses of pure drug (DS), polymers, blank and drug loaded beads were performed using $\mathrm{KBr}$ pellets on a Shimadzu FTIR instrument (JASCO, model 4200 , Japan), compressed in a hydraulic press at 10 tons for 30 seconds.

\section{Differential Scanning Calorimetric Analysis}

The possibility of any interaction between sodium diclofenac and sodium alginate, chitosan, and sodium carboxymethyl cellulose during the formulation was assessed by carrying out thermal analysis on sodium alginate, sodium carboxymethyl cellulose, chitosan, pure drug (sodium diclofenac), empty beads and drug-loaded beads (Mettler TA 4000). The thermograms of the samples were obtained at a scanning rate $10^{\circ} \mathrm{C} / \mathrm{min}$ conducted over a temperature range of $30-300{ }^{\circ} \mathrm{C}$.

\section{X-ray Powder Diffraction Analysis}

The X-ray diffraction patterns of pure Diclofenac sodium, polymers and drug-loaded beads were done and the diffraction pattern of pure drug was compared with the drug-loaded beads. The powder form of samples was exposed to cu radiation $\left(30 \mathrm{KV}^{*} 15 \mathrm{~mA}\right)$ in a wide angle X-ray diffractometer (Miniflex goniometer). The instrument was operated in the continuous mode, in increments of $0.010^{\circ}, 2$ Theta.

\section{RESULT AND DISCUSSION}

\section{Particle size and morphological characteristics}

Mean particle size of the different DS-loaded bead formulations were in the range of $438.29 \pm 0.294 \mu \mathrm{m}$ to $1190.11 \pm 0.944 \mu \mathrm{m}$ shown in (Table II). It was observed that the addition of polymers, SCMC and chitosan resulted in an increase in the particle size as the amount of drug is increased (F6, F7). The particle size of batch F2 was smaller than the particle size of F1 due to addition of sodium carboxymethyl cellulose in the formulation, as alginate and chitosan take longer for the cross-linking and SCMC is a more water-soluble polymer than the other two and leaches out from the formulation, although IR spectra revealed its presence in the formulation. (Figure $1 \mathrm{a}, \mathrm{b}, \mathrm{c}$ ) shows the scanning electron photomicrograph of the surface of DSloaded alginate, SCMC and chitosan microspheres.

The results indicate a proportionate increase in the particle size of beads with increasing amount of drug 


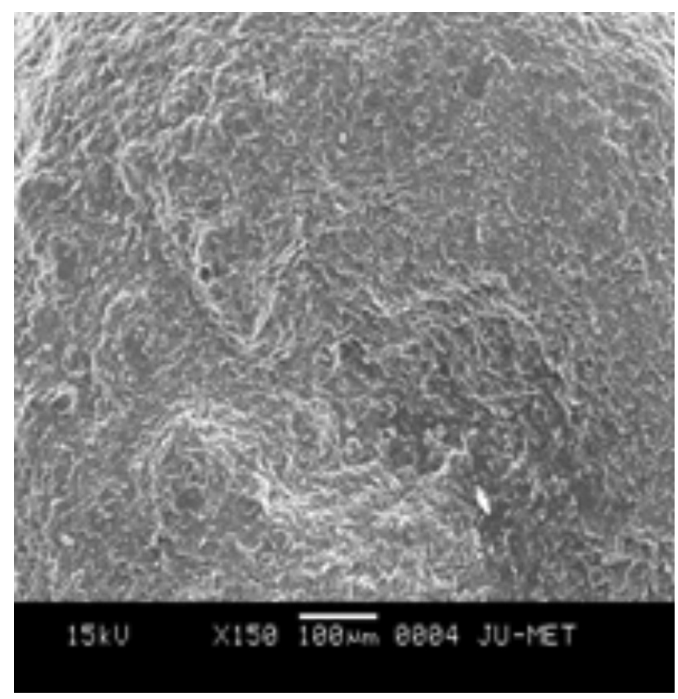

FIGURE 1 (a) -SEM photograph of beads before dissolution (F3).

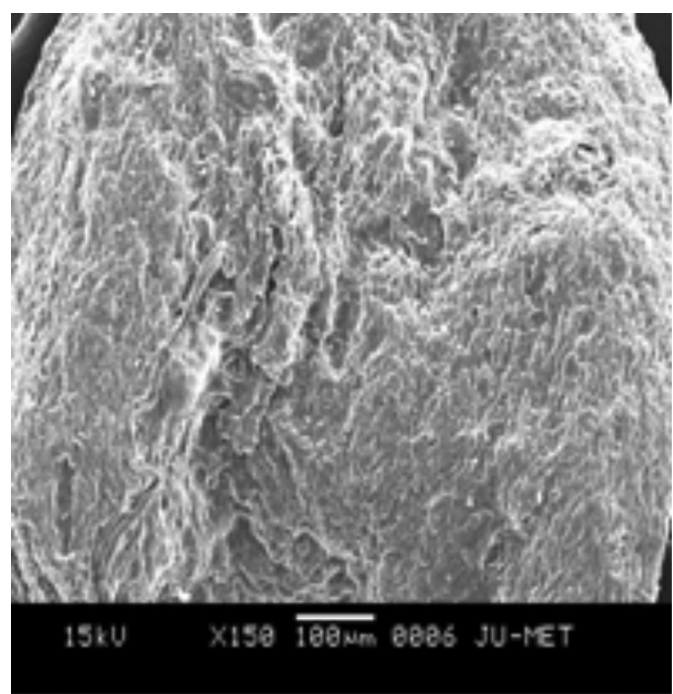

FIGURE 1 (b) - SEM photograph of beads after dissolution (F3).

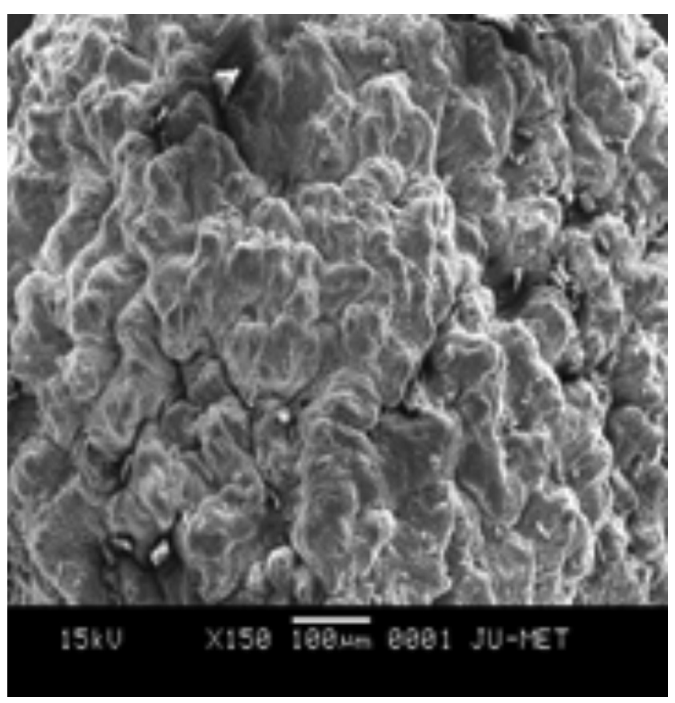

FIGURE 1 (c) -SEM photograph of only alginate beads (F1).

ratio in the formulation (F6, F7). This could be attributed to an increase in diameter by accumulation of a greater percentage of the drug. On the other hand, the mean particle size of beads was found to decrease with an increase in calcium chloride concentration (F8\& F9). It has been stated that when a drop of alginate solution comes in contact with calcium ions, gelation occurs instantaneously. As $\mathrm{Ca}^{+2}$ ions penetrate into the interior of droplets, water molecules are squeezed out from their interior resulting in contraction of beads (Miura et al., 1999). The increase in the size of the beads was clearly evident with increase in the concentration of chitosan in the gelation medium (Anal et al., 2005). Decrease in curing time resulted in a decrease in the particle size (F4, F5).

The SEM photograph of the drug-loaded beads shows that the drug is dispersed in the polymeric matrix as the surface is smooth with absence of any lumps,

TABLE II - Properties and in-vitro drug release of polymeric alginate beads

\begin{tabular}{lcccc}
\hline Formulation code & $\begin{array}{c}\text { Entrapment efficiency } \\
(\%)\end{array}$ & $\begin{array}{c}\text { Particle size } \\
(\mu \mathrm{m})\end{array}$ & $\begin{array}{c}\text { Cumulative percentage } \\
\text { release } \mathrm{pH} 1.2(\%)(*)\end{array}$ & $\begin{array}{c}\text { Cumulative percentage } \\
\text { release } \mathrm{pH} 7.4(\%)(\#)\end{array}$ \\
\hline F1 & $71.66 \pm 1.28$ & $1036.45 \pm 1.143$ & $14.59 \pm 0.179$ & $92.44 \pm 0.269$ \\
F2 & $96.27 \pm 3.68$ & $573.46 \pm 0.74$ & $06.53 \pm 0.844$ & $93.73 \pm 0.761$ \\
F3 & $80.07 \pm 4.35$ & $610.34 \pm 0.418$ & $07.33 \pm 0.926$ & $91.43 \pm 0.799$ \\
F4 & $45.58 \pm 2.17$ & $438.29 \pm 0.294$ & $10.14 \pm 0.434$ & $84.56 \pm 0.564$ \\
F5 & $51.67 \pm 3.27$ & $557.78 \pm 1.13$ & $16.01 \pm 0.546$ & $96.97 \pm 0.356$ \\
F6 & $92.39 \pm 03.4$ & $1190.11 \pm 0.944$ & $04.79 \pm 0.254$ & $96.97 \pm 0.776$ \\
F7 & $95.34 \pm 0.94$ & $948.79 \pm 0.231$ & $08.49 \pm 0.566$ & $94.18 \pm 0.963$ \\
F8 & $87.13 \pm 1.87$ & $770.39 \pm 1.048$ & $10.39 \pm 0.312$ & $93.90 \pm 0.863$ \\
F9 & $74.39 \pm 3.56$ & $839.28 \pm 1.040$ & $13.45 \pm 0.312$ & $97.99 \pm 0.723$ \\
\hline
\end{tabular}


which confirms that this system is a polymeric matrix system. The SEM photographs presented in (Figure 1 $a, b)$ also show difference in the surface morphology of the prepared beads before and after the completion of the in-vitro dissolution study. The surface of beads after dissolution was rougher than before dissolution. The SEM photographs depicted in (Figure $1 \mathrm{c}$ ) indicate greater smoothness in the surface of prepared beads due to the addition of polymers, chitosan and sodium CMC. They also show that the drug is dispersed in polymeric matrix even in the case of beads prepared with different polymers in combination.

\section{Entrapment Efficiency}

Entrapment efficiency was found to be in the range of $45.58 \pm 2.17$ to $96.27 \pm 3.68$, respectively, as shown in (Table II). The variation in concentration of polymers had a profound effect on the loading of sodium diclofenacin alginate beads. The drug loading increases with the addition, as well as with increase in the concentration, of sodium alginate and chitosan (F2, F7). However, the drug-loading capacity decreased in the case of F4 and F5 and this may be due to less gelation time given after the formation of beads. Increase in the concentration of calcium chloride decreases drug loading (F8 \& F9); this may be attributed to increased porosity of the beads (Miura et al., 1999).The drug loading increased with increase in drug-polymer (alginate) ratio.

The variations in concentration of polymers had an effect on entrapment efficiency of DS in alginate beads. In the absence of chitosan, entrapment of the drug is slightly decreased. This may be due to insufficient cross-linking and large pore size permitting the drug to diffuse out during and after gelation (Marsh et al., 1967). Addition of $0.5 \%-0.75 \%$ of chitosan to the gelation medium resulted in an increase in entrapment. The increase in entrapment efficiency may also be attributed to greater availability of active calcium binding sites in the polymeric chains and consequent greater degree of cross-linking as the amount of sodium alginate increases. Since the solubility of DS is slightly higher in calcium chloride solution than in distilled water, prolonged exposure caused greater loss of drug in the curing medium. Increase in the alginate concentration reduced loss of drug in the curing medium due to formation of a dense matrix structure.

\section{Swelling Capacity and erosion study}

The swelling and erosion profiles of F1 as only SA beads and F2, F3, F4 as modified SA beads with different proportions of $\mathrm{CH}$ and $\mathrm{SCMC}$ are given in (Figure 2 and figure 3).

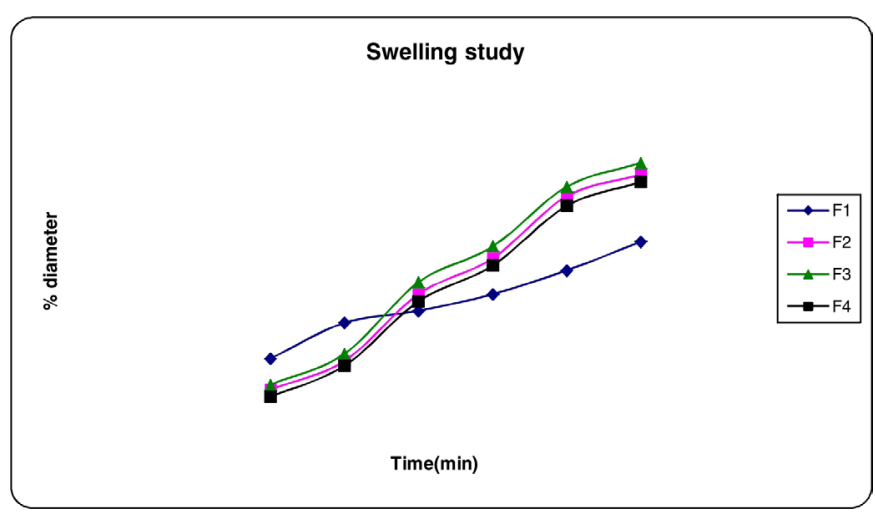

FIGURE 2 - Bead diameter variation (expressed as percentage of diameter increase) after contact with phosphate buffer $\mathrm{pH}$ 7.4(mean \pm S.D.; $n=3)$ : of F1 only SA beads; F2, F3, F4 are SCMC and CH modified SA beads.

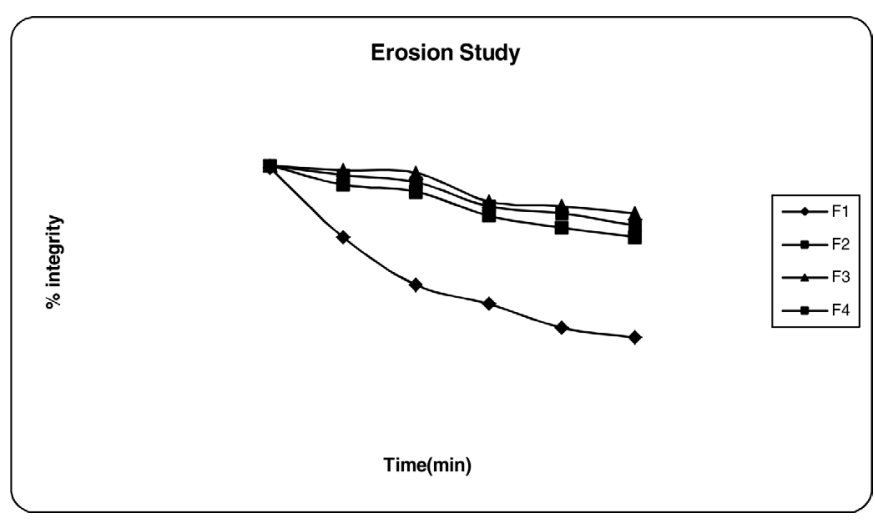

FIGURE 3 -Bead erosion in phosphate buffer $\mathrm{pH} 7.4$ (mean \pm S.D.; $n=3$ ): of F1 only SA beads; F2, F3, F4 are SCMC and CH modified SA beads.

When immersed in distilled water, the SA beads begin immediately to swell, recovering their initial production spherical shape. The \% diameter of SA beads is increased with the increased proportion of SCMC and $\mathrm{CH}$. The swelling rate of beads was obtained from the slope of the relationship between the \% diameter and the square root of time. This relationship provided good linearity with R2 of more than 0.98 when analyzed by linear regression analysis in Table III. The swelling rate of beads tended to increase as the concentration of SCMC increased. Using phosphate buffer, the swelling rate of the beads cannot be estimated because of quick erosion. Water uptake increases with time, leading to an initial loss of spherical shape within $1 \mathrm{~h}$. On the other hand, crosslinked SA beads exhibit an initial faster diameter increase, 
TABLE III - Swelling rates of Sodium alginate and modified SA beads

\begin{tabular}{lc}
\hline Formulation & Swelling rate $(\mathrm{cm} / \mathrm{s})$ \\
\hline F1 & $09.09(0.98)$ \\
F2 & $19.03(0.99)$ \\
F3 & $19.20(0.98)$ \\
F4 & $19.71(0.98)$ \\
\hline
\end{tabular}

which slows down after 15 min while keeping their shape. Incorporation of SCMC and $\mathrm{CH}$ promoted the swelling properties because both provided higher water uptake capacity than SA.

In the erosion tests performed in phosphate buffer $\mathrm{pH} 7.4$, both types of beads exhibited an initial increase in volume. The SA beads started to erode significantly at 30-45 min and their spherical form vanished after 120$180 \mathrm{~min}$, whereas the cross-linked formulations kept their shape throughout the test ( $80 \%$ integrity after $5 \mathrm{hr}$ ). This feature was also observed during the entire drug release tests and probably is the main cause of the diclofenac prolonged release profile from beads.

\section{In vitro Drug Release studies}

The release profiles of DS in the enzyme-free gastric fluid (SGF) followed by enzyme-free intestinal fluid from the alginate beads are shown in (Figure 4, 5 and 6). The drug release from alginate beads depends on the penetration of the dissolution of medium into beads, the eventual swelling and diffusion through the swollen matrix, dissolution of the alginate matrix and subsequent dissolution of the leached out drug. In SGF, the beads released $4-16 \%$ DS in the first $2 \mathrm{~h}$ and after that the rest of the drug in the SIF which continues up to $9 \mathrm{~h}$ where $84-97 \%$ of the drug was released, as shown in Table II. The burst effect was not found during the release of the drug, which may be due to its water insoluble nature.

The effect of the different concentrations of polymers used (SA- 3\% \& 4\% w/v, SCMC- $0.5 \% \& 1 . \%$ $\mathrm{w} / \mathrm{v}$, chitosan- $0.5 \% \& 0.75 \% \mathrm{w} / \mathrm{v}$ ) was also observed. The release of drug from the polymeric matrix decreased due to addition of polymer. Polymers such as sodium alginate, sodium carboxymethyl cellulose and chitosan entrapped the drug more tightly in the polymeric matrix (Martisen et al., 1989). Concentration of polymers, sodium alginate, sodium carboxymethyl cellulose and chitosan, when increased, lead to slower drug release. When the concentration of sodium alginate increases, cumulative release decreases from $96.97 \pm 0.776 \%$ to $94.18 \pm 0.963 \%$

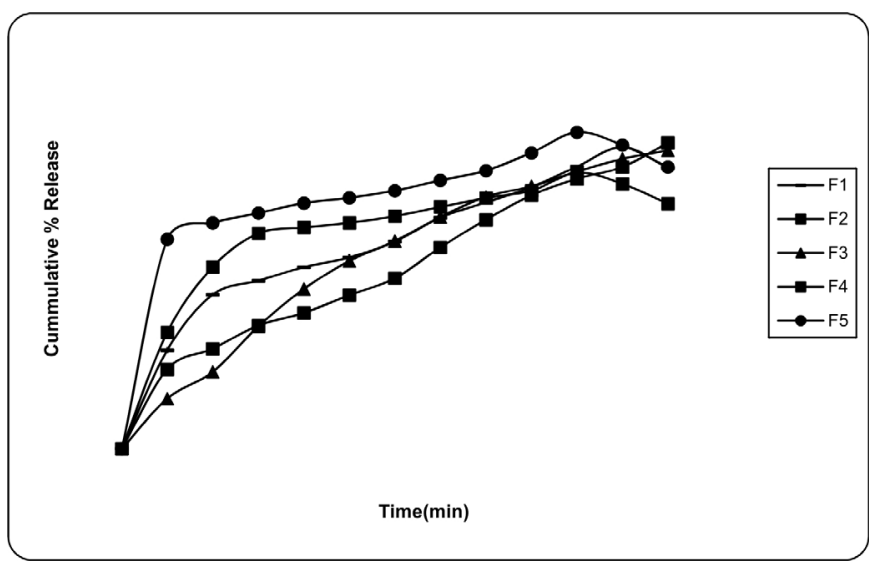

FIGURE 4 -Comparative results of in vitro release profile of different proportions of $\mathrm{SA}, \mathrm{CH}$, and $\mathrm{SCMC}$ beads of sodium diclofenacin phosphate buffer $\mathrm{pH} 7.4$.

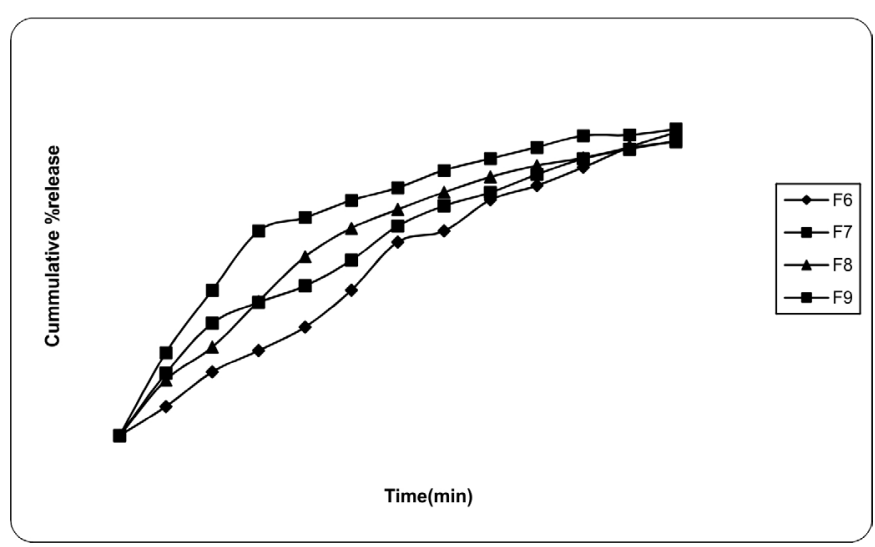

FIGURE 5 - Comparative results of in vitro release profile of different proportions of $\mathrm{SA}, \mathrm{CH}$, and $\mathrm{SCMC}$ beads of sodium diclofenacin phosphate buffer $\mathrm{pH}$ 7.4.

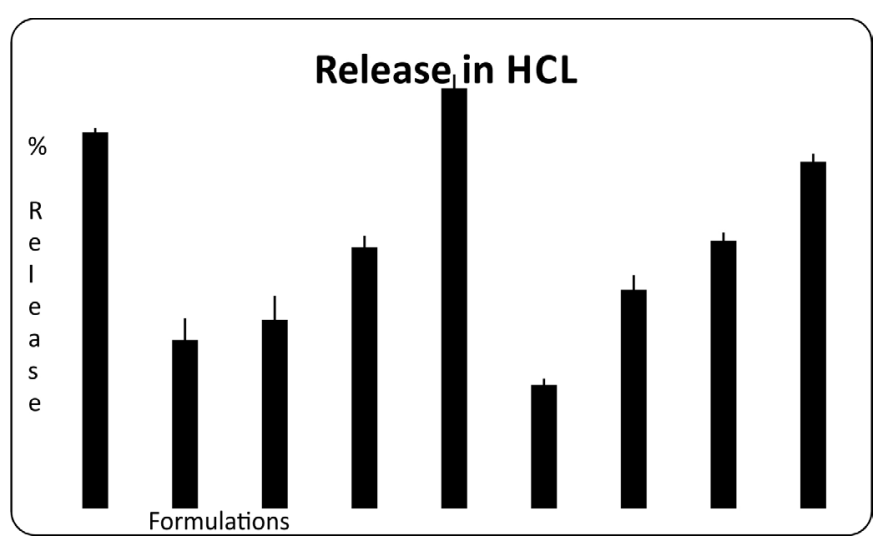

FIGURE 6 - Comparative results of in vitro release profile of different proportions of $\mathrm{SA}, \mathrm{CH}$, and $\mathrm{SCMC}$ beads of sodium diclofenacin hydrochloric acid buffer $\mathrm{pH} 0.1$.

(F6, F7). In the case of the other two polymers, these also showed the same result. The cumulative release of drug after $8 \mathrm{~h}$ decreased from $96.97 \pm 0.356 \%$ to $84.56 \pm 0.564 \%$ 
(F5, F4) and from $96.97 \pm 0.776 \%$ to $94.18 \pm 0.963 \%$ (F6, F7) as the concentration of Sodium carboxymethyl cellulose and chitosan increased, respectively. The decrease in the rate of drug release is much slower when the concentrations of both the polymers increase than with increase in the concentration of only one polymer, as exemplified by the release profile of batch $\mathrm{F} 4$ where the maximum drug release was $84.56 \pm 0.564 \%$ after $8 \mathrm{~h}$.

\section{Release Kinetics for DS-loaded beads}

To determine the mechanism of drug release from these formulations, the data were treated with various models such as zero-order, first-order, Higuchi, and Korsmeyer-Peppas. Different results were obtained and the models which best fit the drug release from different formulations are shown in (Table IV). From the linear regression analysis, the coefficient of determination $\left(\mathrm{r}^{2}\right.$ was in range 0.9090 to 0.9967 ) indicated that the data corresponds to a diffusion-controlled mechanism, as suggested by Higuchi (Anal et al., 2005).

\section{FT-IR Spectroscopic Analysis}

FT-IR of DS showed that the principle IR peak at $1284 \mathrm{~cm}^{-1}$ resulted from $\mathrm{C}-\mathrm{N}$ stretching and peaks $1504 \mathrm{~cm}^{-1}$ and $1576 \mathrm{~cm}^{-1}$ resulted from $\mathrm{C}=\mathrm{C}$ stretching and $\mathrm{C}=\mathrm{O}$ stretching of carboxylate group, respectively (Figure 7 a,b,c,d,e). The IR peaks of DS-loaded SA-SCMC-CH beads displayed a combination of unshifted principle peaks of drug.

In the FT-IR spectrum of sodium alginate powder, the various distinct peaks of alginate evident are those of the hydroxyl group at $3429 \mathrm{~cm}^{-1}$, carbonyl at $1609 \mathrm{~cm}^{-1}$ and carboxyl and carboxylate groups between 1000 and $1400 \mathrm{~cm}^{-1}$. The absorption band around 2880, 1656, 1421 and $1080 \mathrm{~cm}^{-1}$ corresponds to the stretching of $-\mathrm{CH}, \mathrm{COO}-,-\mathrm{CH}$ and C-O-C, respectively. In the FT-IR spectrum of the drug-loaded beads/formulation, the band $2880 \mathrm{~cm}^{-1}$, which corresponds to pure chitosan, was

TABLE IV -Correlation co-efficient of different kinetics models for drug-loaded beads (Drug release studies pH 7.4)

\begin{tabular}{lcccc}
\hline Formulation code & $\begin{array}{c}\text { Zero order } \\
\mathrm{r}^{2}\end{array}$ & $\begin{array}{c}\text { First order } \\
\mathrm{r}^{2}\end{array}$ & $\begin{array}{c}\text { Higuchi } \\
\mathrm{r}^{2}\end{array}$ & $\begin{array}{c}\text { Peppas-Korsmeyer } \\
\mathrm{r}^{2}\end{array}$ \\
\hline F1 & 0.7649 & 0.9856 & 0.9892 & 0.5387 \\
F2 & 0.6819 & 0.9907 & 0.9760 & 0.5183 \\
F3 & 0.8144 & 0.9898 & 0.9755 & 0.5919 \\
F4 & 0.5184 & 0.9669 & 0.9349 & 0.4792 \\
F5 & 0.7871 & 0.9901 & 0.9853 & 0.5449 \\
F6 & 0.9051 & 0.9926 & 0.9853 & 0.6146 \\
F7 & 0.5148 & 0.9969 & 0.9712 & 0.4792 \\
F8 & 0.8394 & 0.9962 & 0.9850 & 0.5794 \\
F9 & 0.8771 & 0.9290 & 0.9874 & 0.5737 \\
\hline
\end{tabular}

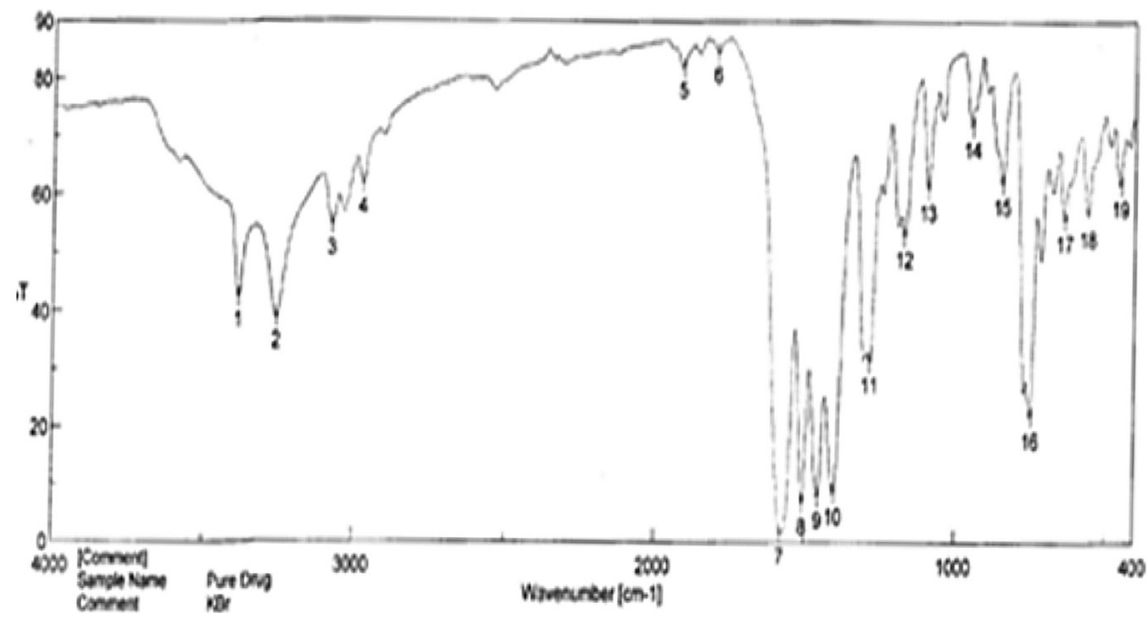

FIGURE 7 (a) - FTIR Spectroscopic analysis of pure sodium diclofenac. 


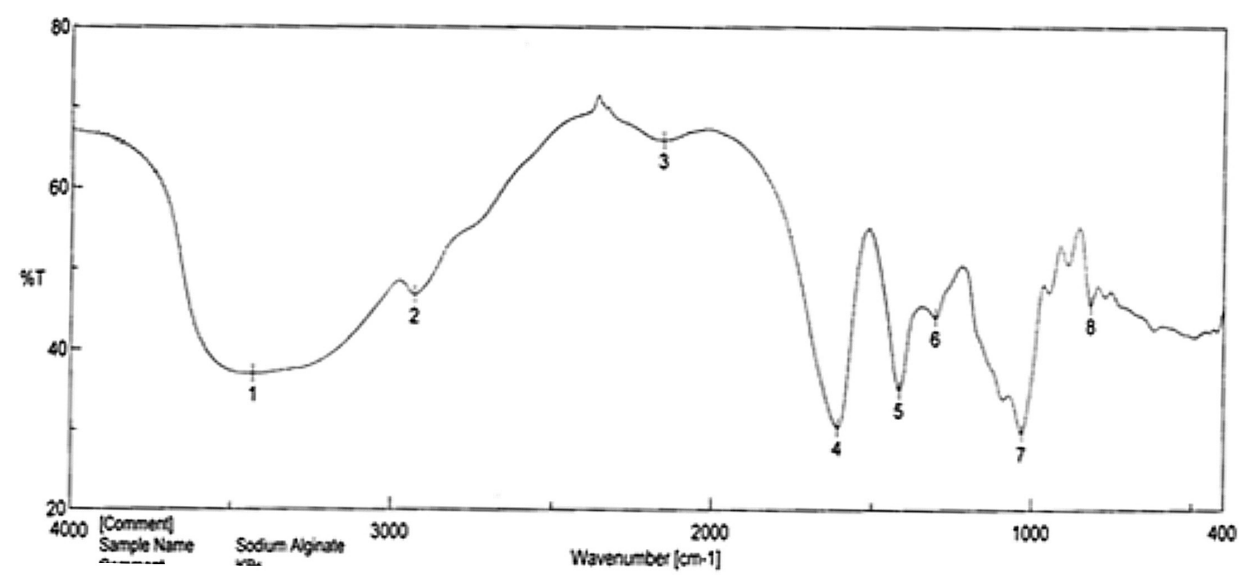

FIGURE 7 (b) - FTIR Spectroscopic analysis of sodium alginate alone.

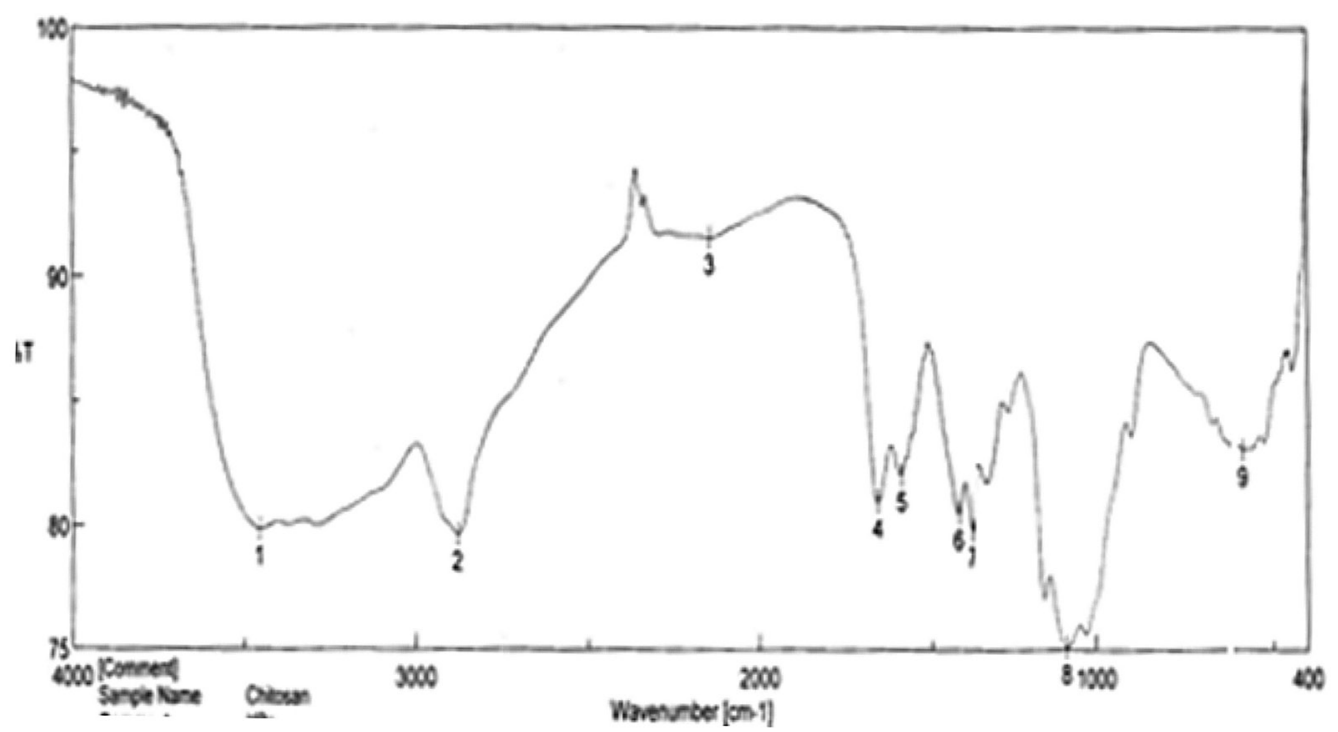

FIGURE 7 (c) - FTIR Spectroscopic analysis of sodium carboxymethyl cellulose.

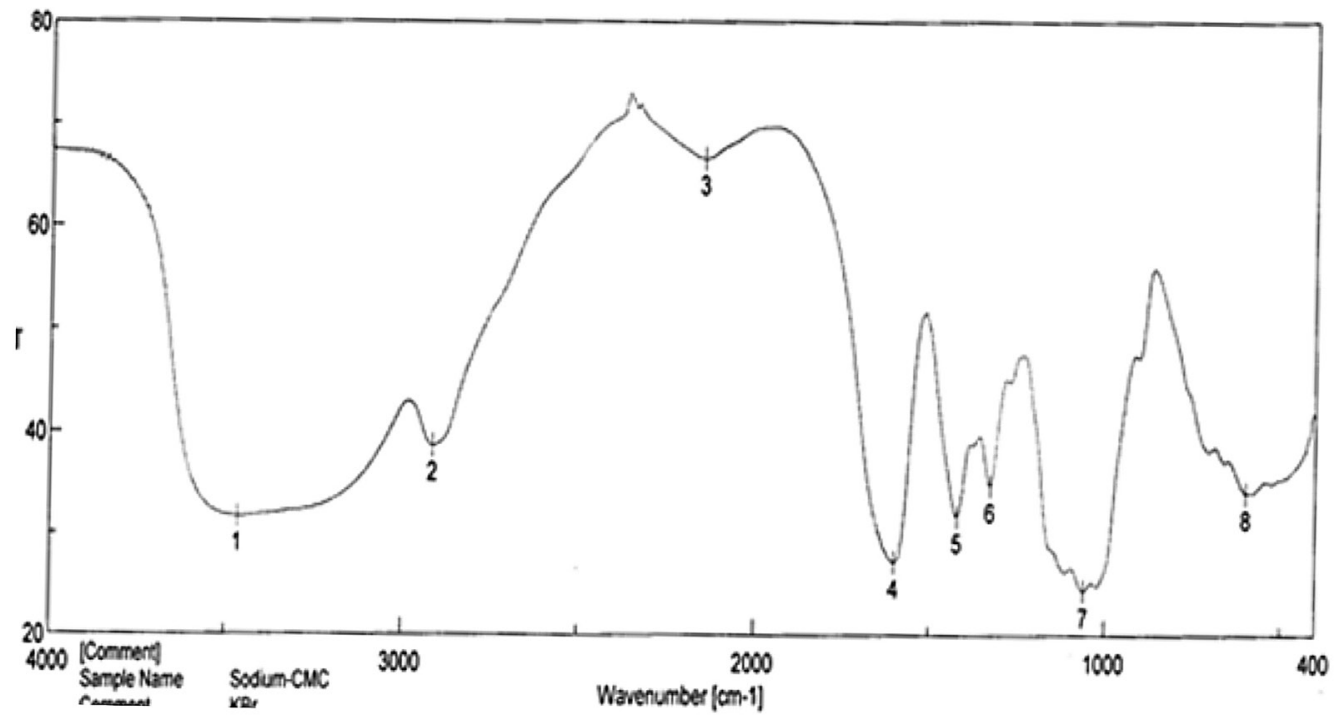

FIGURE 7 (d) -FTIR Spectroscopic analysis of chitosan. 


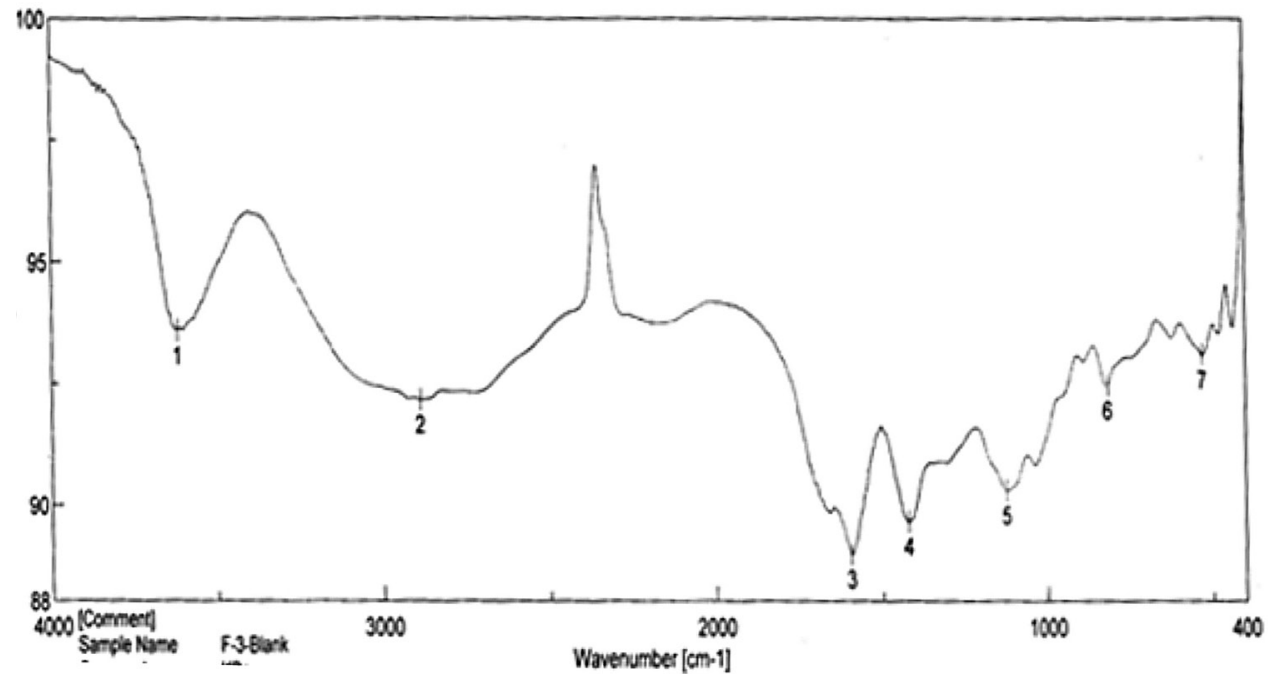

FIGURE 7 (e) -FTIR Spectroscopic analysis of formulation F2.

shifted to $3070 \mathrm{~cm}^{-1}(\mathrm{~F} 2) / 2889 \mathrm{~cm}^{-1}$ (F2 blank) indicating the confirmation of complex formation between chitosan and sodium alginate. It can be concluded that interactions between polymers which formed the matrix and drug did not occur during the preparation of the drug-loaded beads.

\section{Differential scanning colorimetric studies}

The comparative DSC thermograms of DS, SA, $\mathrm{CH}, \mathrm{SCMC}$, blank and drug-loaded beads are given in (Figure $8 \mathrm{a}, \mathrm{b}, \mathrm{c}, \mathrm{d}, \mathrm{e}$ ). DSC tracings of pure DS show an exothermic peak at $275.28^{\circ} \mathrm{C}$ which corresponds to its melting point. The DSC curve of empty beads is different from the polymer (SA), indicating the confirmation of interaction between SA and Calcium ions (Sah et al., 1994). Sodium alginate decomposed at about $240{ }^{\circ} \mathrm{C}$ with an exotherm. The peak of the drug did not appear in the thermograms of beads containing DS. Therefore, the absence of the exothermic peak of DS at around $275^{\circ} \mathrm{C}$ in the DSC thermogram of the drug-loaded beads suggests that the drug existed in an amorphous state as a molecular dispersion in the polymeric matrix. In the beads containing drug, there was no characteristic exothermic peak observed except for one exothermic peak in the $169-200{ }^{\circ} \mathrm{C}$ range which may be due to shifting of the peak of SA from its original position in the DSC thermogram of the polymer alone. This may also indicate that sodium alginate interacts with the other polymers and forms a homogeneous dispersion.

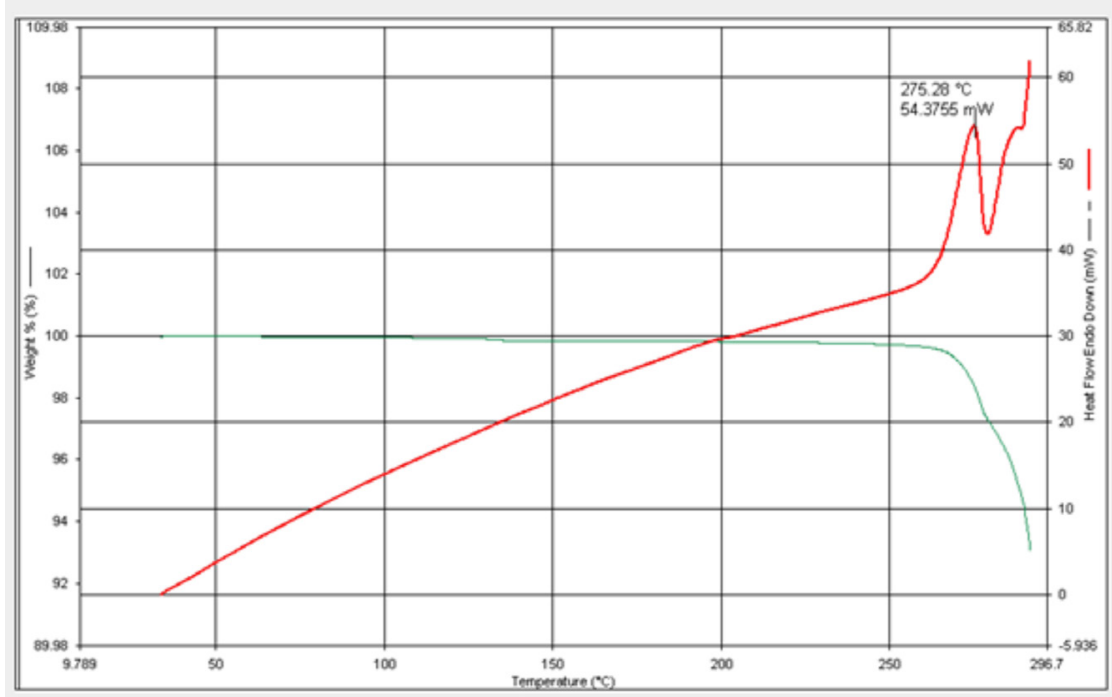

FIGURE 8 (a) - Differential Scanning calorimetric analysis of pure drug sodium. 


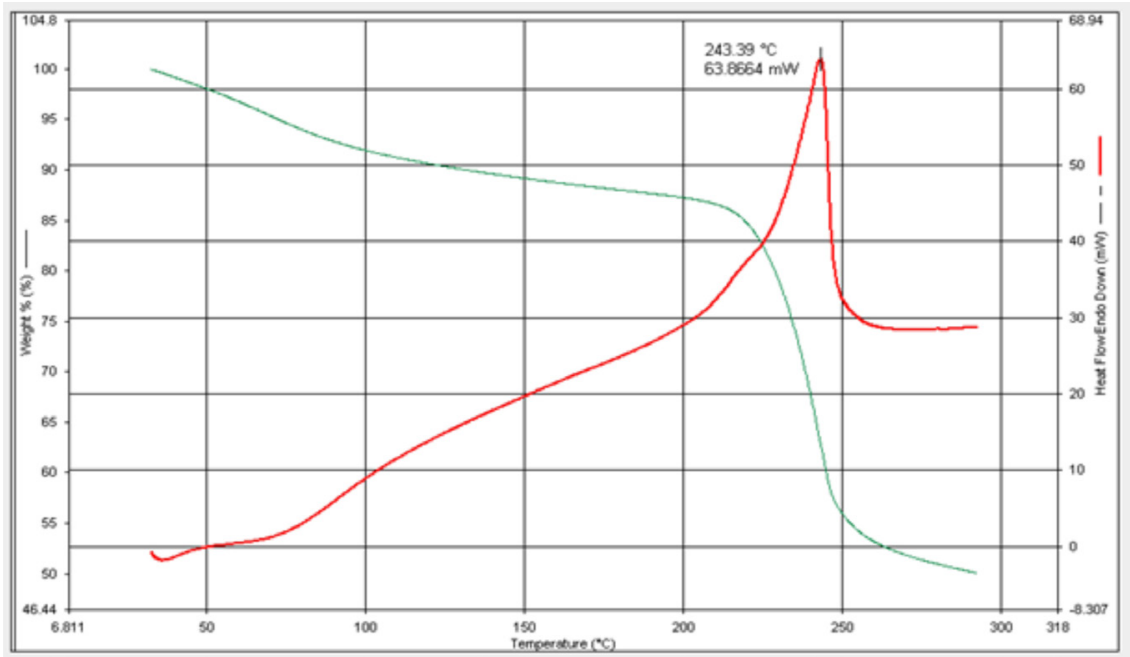

FIGURE 8 (b) - Differential Scanning calorimetric analysis of sodium alginate alone.

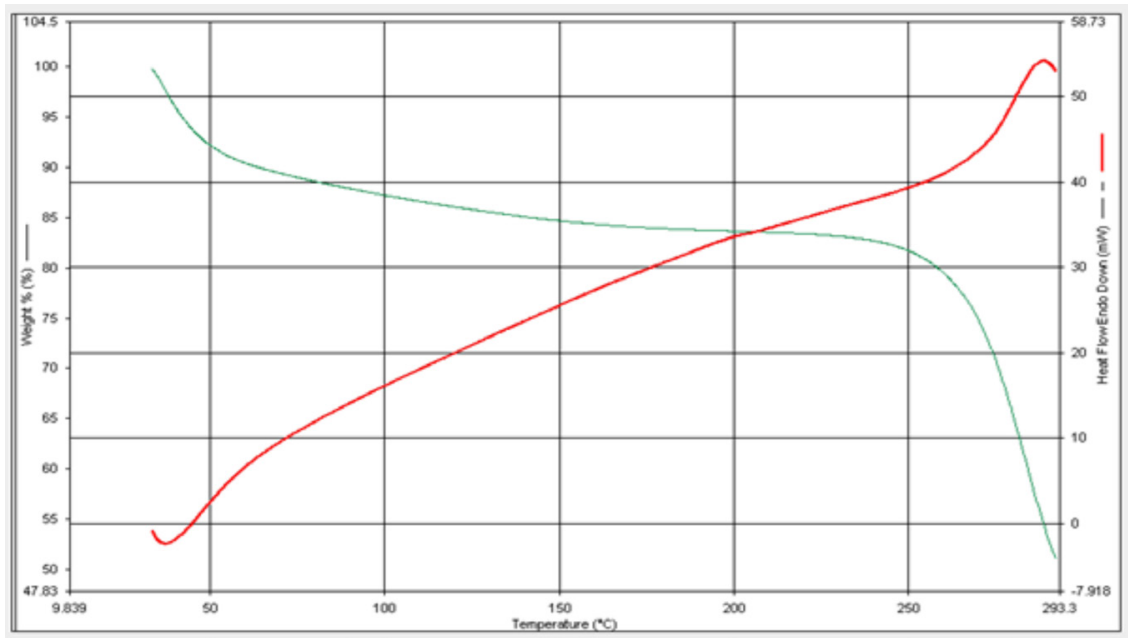

FIGURE 8 (c) -Differential scanning calorimetric analysis of sodium carboxymethyl cellulose.

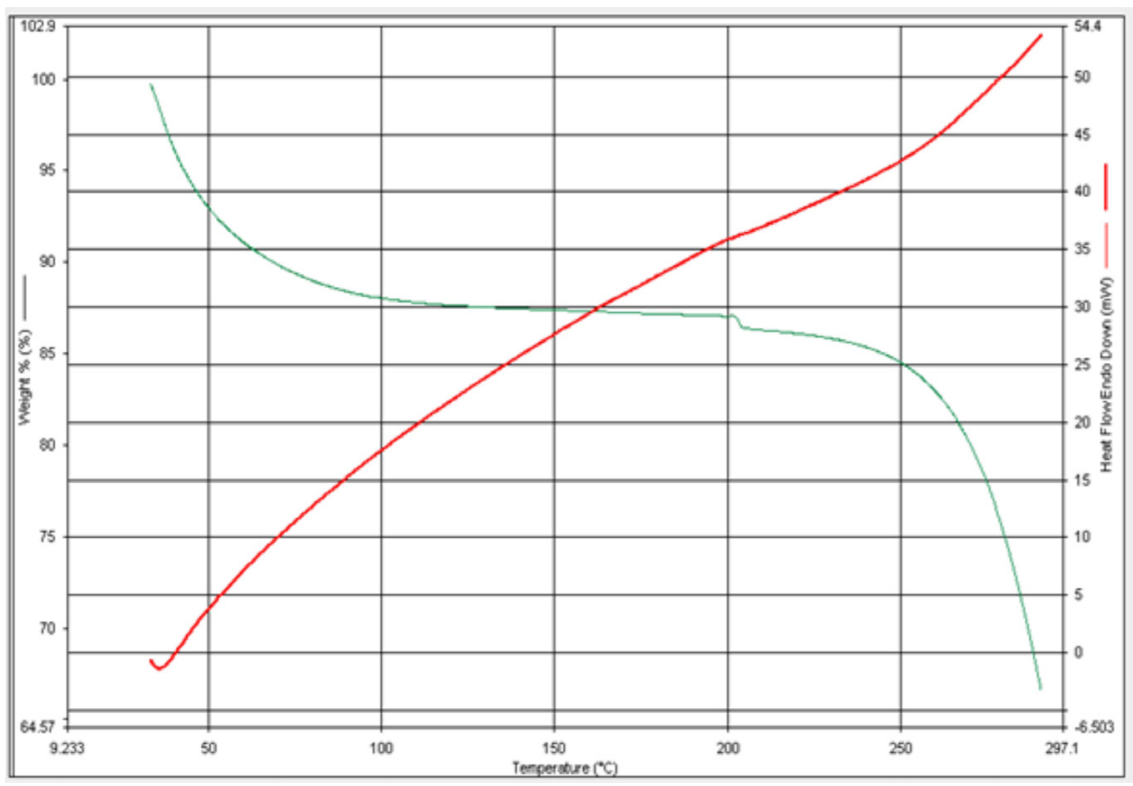

FIGURE 8 (d) - Differential scanning calorimetric analysis of chitosan. 


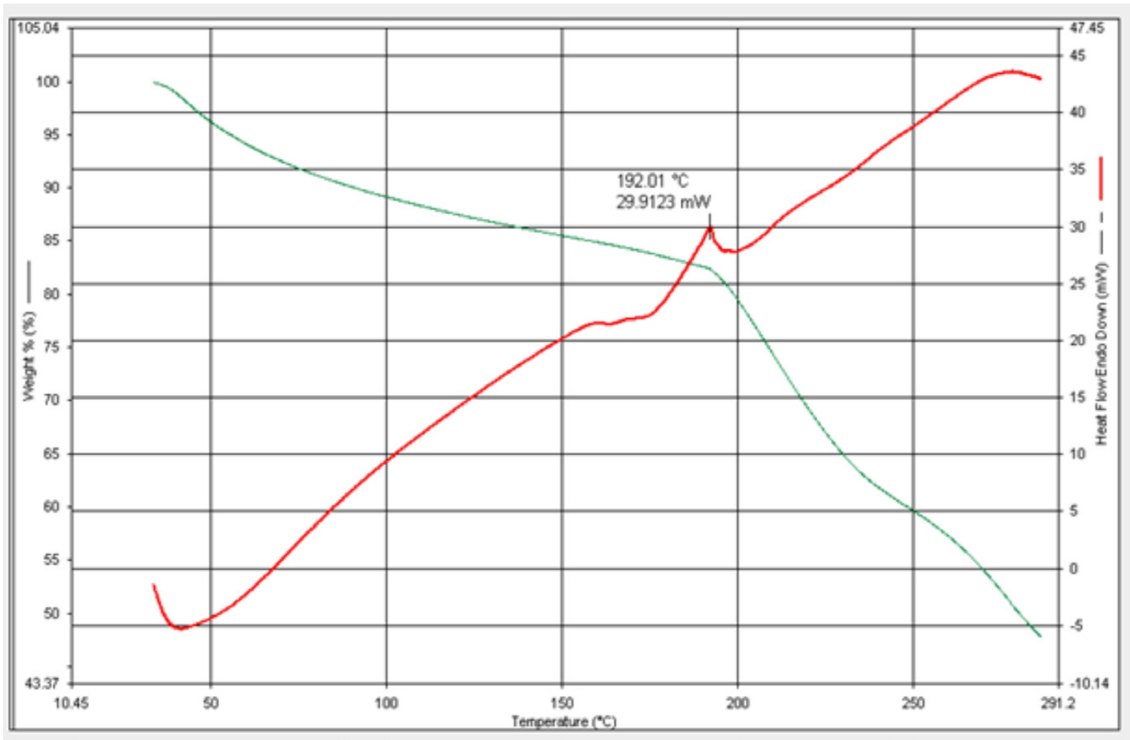

FIGURE 8 (e) - Differential scanning calorimetric analysis of formulation F2.

\section{X-Ray diffraction study}

In order to confirm the physical state of the drug in the beads, X-ray diffraction studies of the pure drug, polymers, empty beads and drug-containing beads were carried out and the diffractograms shown in (Figure 9 $\mathrm{a}, \mathrm{b}, \mathrm{c}, \mathrm{d}, \mathrm{e})$. From the X-ray diffraction data of drugloaded beads, it was seen that no crystalline state of drug was detected in drug-loaded beads. This means that the drug was not present in the crystalline form in the bead matrix, but in an amorphous state. This clearly indicates that changes in the crystalline state of the drug occurred during the preparation of beads by this ionotropic gelation method.

\section{CONCLUSION}

This study showed that drug-loading and release characteristics of DS-loaded alginate beads, alginatechitosan beads, and alginate-chitosan-SCMC beads are dependent on the presence of a polyelectrolyte complex between alginate and chitosan; calcium chloride

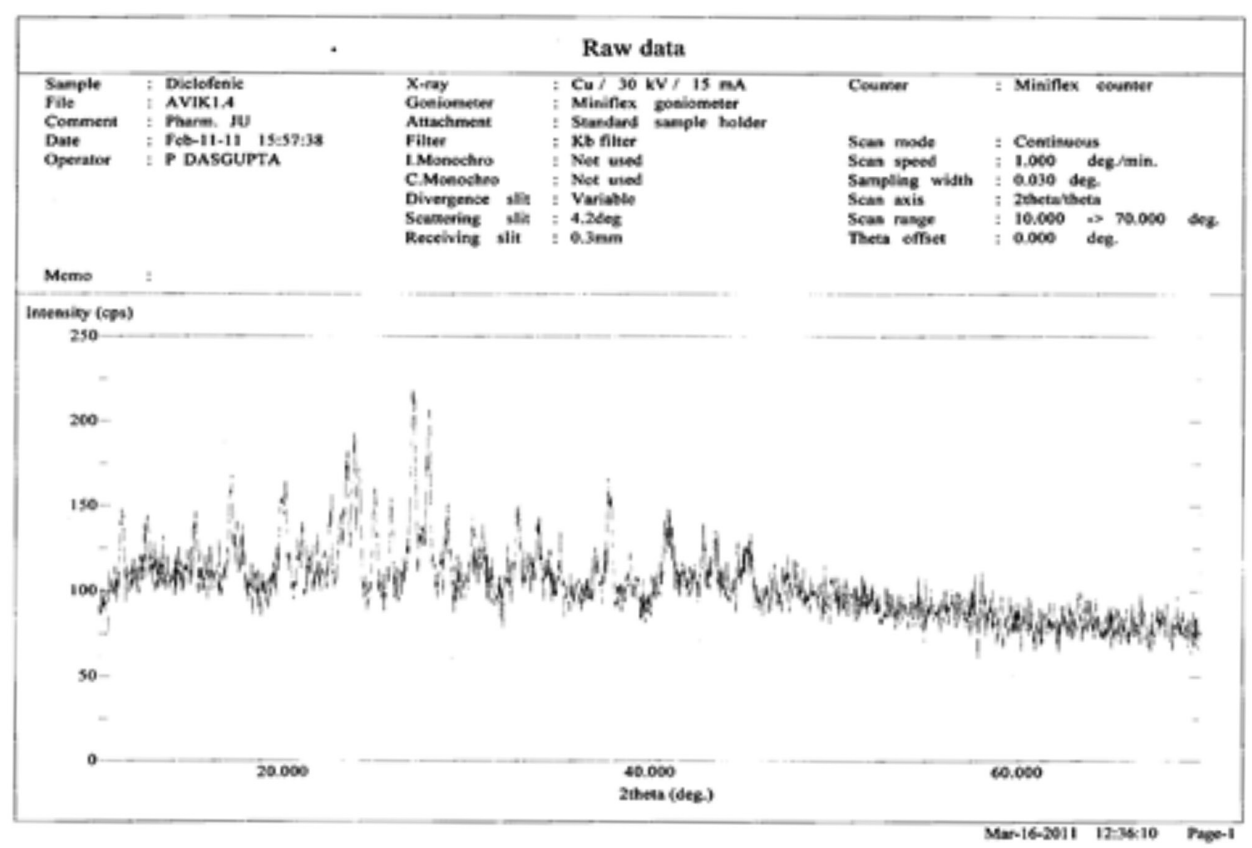

FIGURE 9 (a) - X-ray diffraction analysis of pure drug diclofenac sodium. 


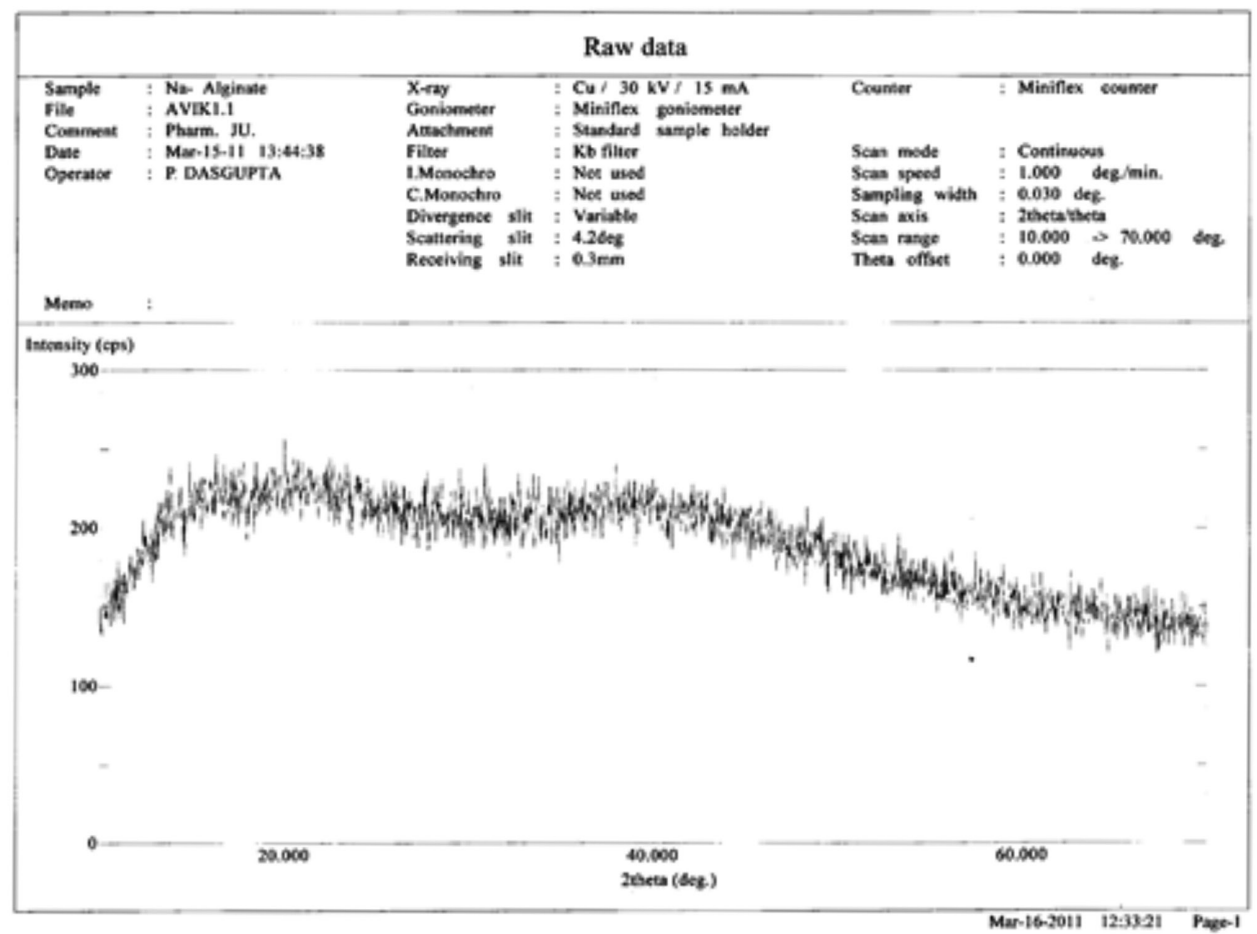

FIGURE 9 (b) - X-ray diffraction analysis of sodium alginate alone.

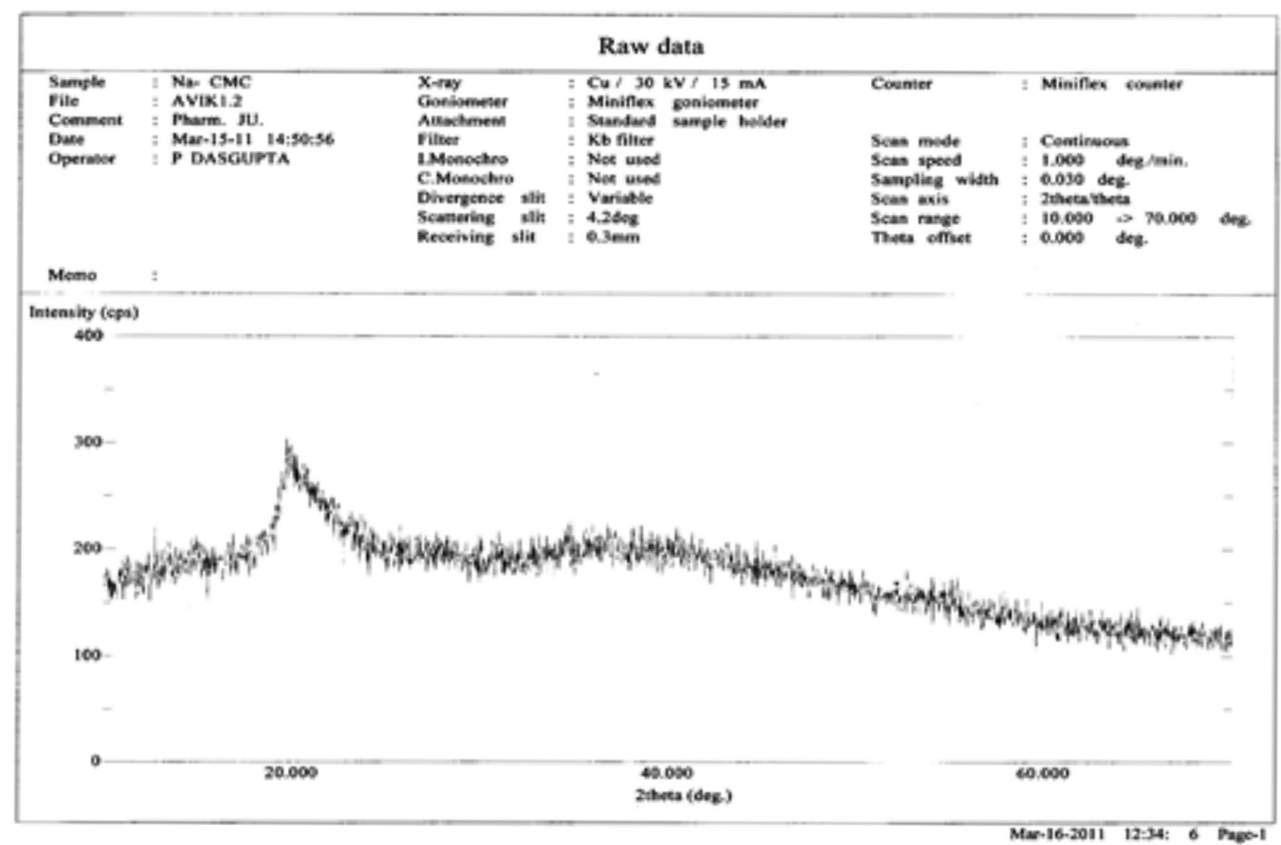

FIGURE 9 (c) -X-ray diffraction analysis of sodium carboxymethyl cellulose.

concentration in the gelation medium, drug to polymer ratio, and $\mathrm{pH}$ of the dissolution medium. The FT-IR studies revealed that no drug polymer interaction occurred during the preparation of the beads. DSC and XRD studies qualitatively confirmed the physical state of the drug sodium diclofenacin the beads. The XRD studies revealed the absence of crystalline peaks, indicating that the drug is well dispersed in the polymeric matrix at the molecular level. In vitro release studies revealed that drug release of alginate beads can be reduced considerably by treating alginate beads with chitosan and that further treatment with alginate coating of the different beads prolonged the release of Sodium diclofenacto a small extent. It was found that the in vitro drug release of all the batches was 


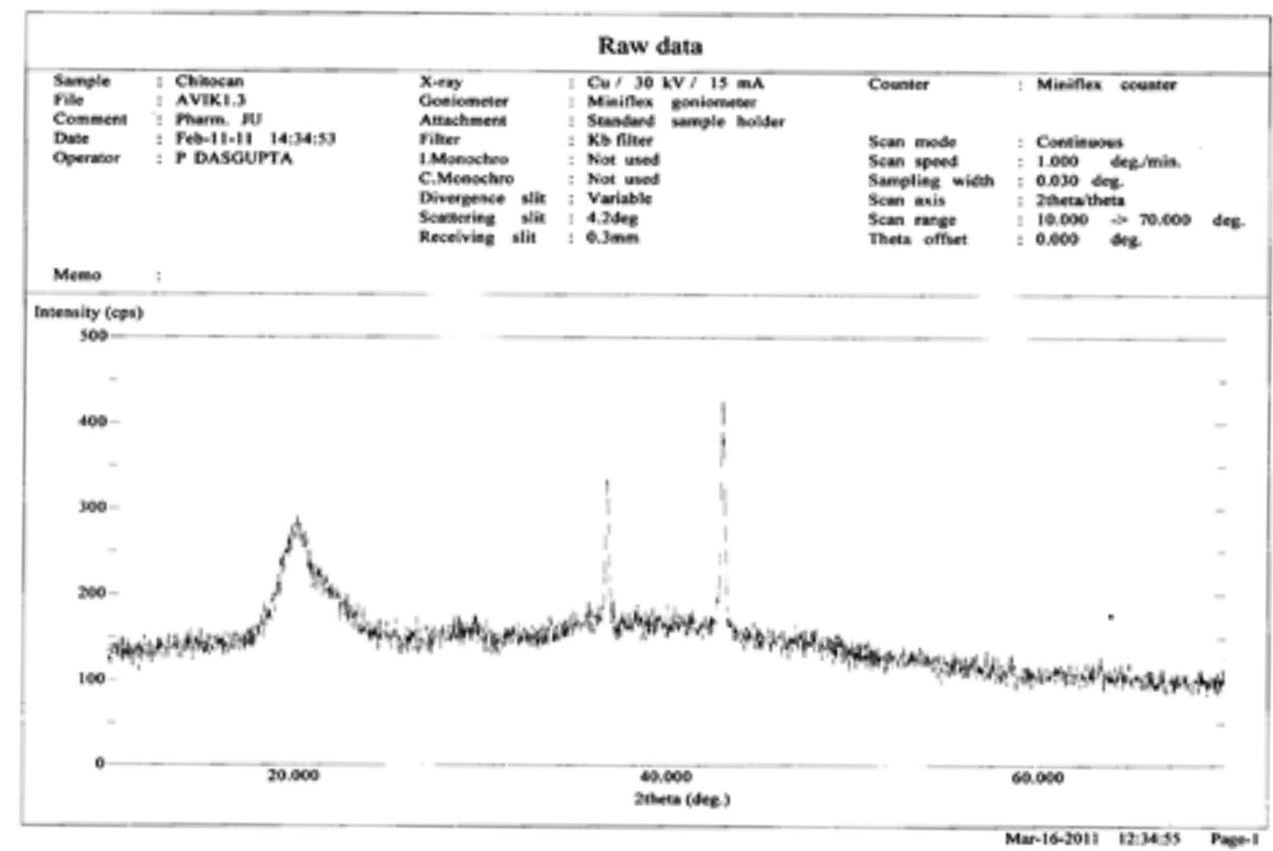

FIGURE 9 (d) -X-ray diffraction analysis of chitosan.

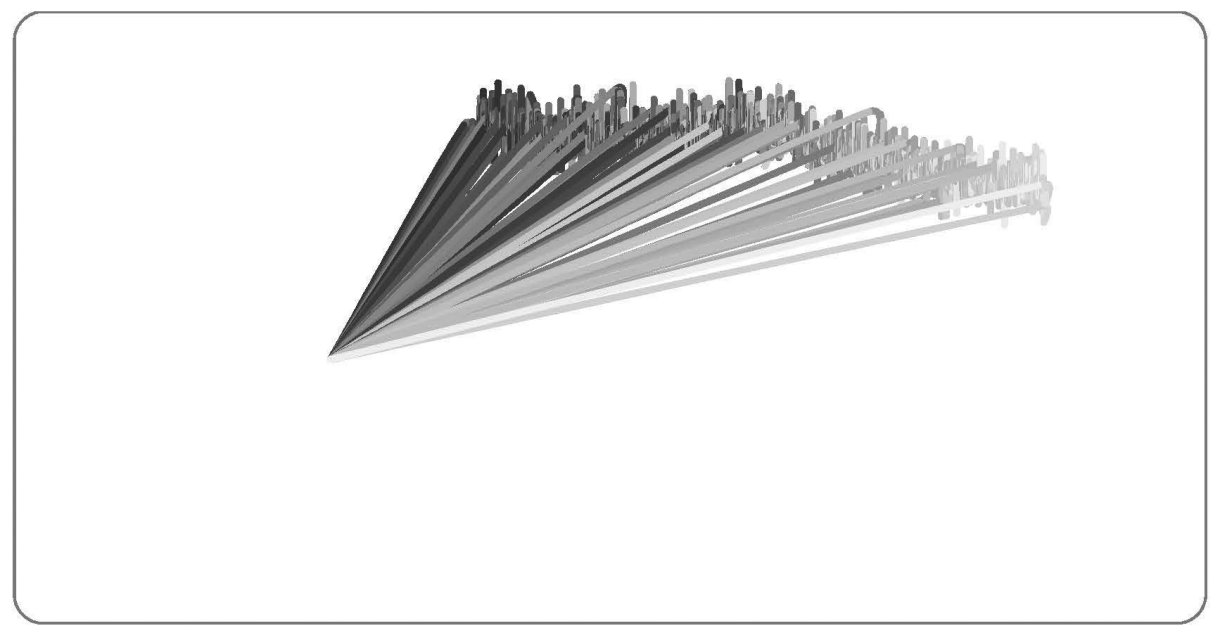

FIGURE 9 (e) - X-ray diffraction analysis of formulation F2.

best explained by first-order kinetics as these plots showed the highest linearity, indicating that the drug release was closely dependent on concentration. Drug diffused at a comparatively slower rate as the distance for diffusion increased, referred to as Higuchi's kinetics.

\section{REFERENCES}

ANAL, A.K.; BHOPATKAR, D.; TOKURA, S.; TAMURA, H.; STEVEN, W.F. Chitosan-alginate multilayer beads for gastric passage and controlled intestinal release of protein. Drug. Dev. Ind. Pharm., v.29, n.6, p.713-724, 2003.
ANAL, A.K.; STEVENS, W.F. Chitosan-alginate multilayer beads for controlled release of ampicillin. Int. J. Pharm., v.290, n.1-2, p.45-54, 2005.

BASU, S.K.; RAJENDRAN, A. Development of nateglinide loaded calcium alginate and chitosan coated alginate beads. Chem. Pharm. Bull., v.56, n.8, p.1077-1048, 2008.

BAJPAI, S.K.; SHARMA, S. Investigation of swelling/ degradation behavior of alginate beads crosslinked with $\mathrm{Ca}^{2+}$ and $\mathrm{Ba}^{2+}$ ions. React. Funct. Polym., v.59, n.3, p.129140, 2004. 
BODMIER, R.; PAERATAKUL, O. Spherical agglomerates of water-insoluble drugs. J. Pharm. Sci., v.78, n.4, p.964$967,1989$.

EDITH, M.; MARK, R.K. Microencapsulation: encyclopedia of controlled release. London: John Wiley and sons Inc. London, 1999. v.2, p.520-538.

FERNADEZ- HERVAS, M.J.; HOLGADO, M.A.; FINI, A.; FELL, J.T. In vitro evaluation of alginate beads of a diclofenac salt. Int. J. Pharm., v.163, n.2, p.23-34, 1998.

GIRHEPUNJE, K.M.; PAL, R.S.; GEVARIYA, H.B. Celecoxib loaded microbeads: a targeted drug delivery for colorectal cancer. Int. J. Curr. Pharm. Res., v.2, n.1, p.46-55, 2010.

GONZALEZ-RODRIGUEZ, M.L.; HOLGADO, M.A.; SANCHEZ-LAFUENTE, C.; RABASLO, A.M.; FINI, A. Alginate/chitosan particulate systems for sodium diclofenac release. Int. J. Pharm., v.232, n.3, p.225-234, 2002.

GRIFFITH, L.G. Polymeric biomaterials. Acta Materialia, v.48, n.1, p.263-277, 2000.

KIM, T.K.; PARK, Y.H.; KIM, K.J.; CHO, C. Release of albumin from chitosan coated pectin beads in vitro. Int. J. Pharm. Sci., v.250, n.4, p.371-383, 2003.

LEE, K.Y.; PARK, W.H.; HA, W.S. Polyelectrolyte complexes of sodium alginate with chitosan or its derivatives for microcapsules. J. Appl. Polym. Sci., v.63, n.1, p.425-432, 1996.

MANJANUA, K.M. Sodium diclofenac microbeads for oral sustained release drug delivery. Int. J. PharmTech. Res., v.1, n.2, p.317-327, 2009.

MARSH, J.R.; WEISS, P.J. Solubility of antibiotics in twenty six solvents. J. Ass. Off. Anal. Chem., v.50, n.8, p.437-462, 1967.

MARTISEN, SKJK-BRAEK, G.; SMIDSROD, O. Alginate as immobilization material. Biotechnol. Bioeng., v.33, n.???, p.79-89, 1989.

MIURA, K. Effect of different cations and the curing time for the development of diclofenac microsphere. Carbohydr. Polym., v.39, n.???, p.139-143, 1999.
OUWERX, C.; VELINGS, N.; MESTDAGH, M.M.; AXELOS, M.A. Physico-chemical properties and rheology of alginate gel beads formed with various divalent cations. Polym. Gels Networks, v.6, n.5, p.393-408, 1998.

PARFITT, K. The complete drug reference. Part.I. Antiinflammatory drugs and antipyretics. 32.ed. Philadelphia Pharmaceutical Press, 1996. p.1-11.

PETER, M. New hopes for NSAIDs. Eastern Pharmacist, v.3, n.2, p.3340, 1997.

PRAJAPATI, V.; BANSAL, M.; SHARMA, P.K. Mucoadhesive buccal patches and use of natural polymer in its preparation. Int. J. Pharm. Tech. Res., v.4, n.2, p.582-589, 2012.

RASMUSSEN, M.R.; SNABE, T.; PEDERSEN, L.H. Numerical modelling of insulin and amyloglucosidase release from swelling Ca-alginate beads. J. Controlled Release., v.91, n.3, p.395-405, 2003.

REMUNAR-LOPEZ, C.; LORENZO-LAMOSA, M.L.; VILAJATO, J.L.; ALONSO, M.J. Development of new chitosancellulose multicore mocroparticles for controlled drug delivery. Eur. J. Pharm. Biopharm., v.45, n.4, p.49-56, 1998.

SAH, H.K.; TODDYWALA, R.; CHIEN, Y.W. Microencapsulation techniques using ethyl acetate as a dispersed solvent: effects of its extraction rate on the characteristics of PLGA microspheres. J. Controlled Release., v.30, n.2, p.201-211, 1994.

SANIL, O.; AY, N.; ISIKLAN, N. Release characteristics of sodium diclofenac from poly(vinyl alcohol)/ sodium alginate and poly (vinyl alcohol)-grafted poly(acrylamide)/ sodium alginate blend beads. Eur. J. Pharm. Biopharm., v.65, n.1, p.204-214, 2007.

SEMALTY, M.; SEMALTY, A.; KUMAR, G. Formulation and characterization of mucoadhesive buccal films of glipizide indian. J. Pharm. Sci., v.70, n.1, p.43-48, 2008.

SEZER, A.D.; AKBUGA, J. Release characteristics of chitosan treated alginate beads: II. Sustained release of a low molecular drug from chitosan treated alginate beads. $J$. Microencapsulation, v.16, n.6, p.687-696, 1999.

SIPAHIGIL, O.; GURSOY, A.; CAKALAGAOGLU, F.; OKAR, I. Release behavior and biocompatibility of drugloaded pH sensitive particles. Int. J. Pharm., v.311, n.2, p.130-138, 2006. 
TORRE, P.M.; ENOBAKHARE, Y.; TORRADO, G.; TORRADO, S. Release of amoxicilline from polyionic complexes of chitosan and poly (acrylic acid) study of polymer/polymer and polymer/drug interactions within the network structure. Biomaterials, v.24, n.3, p.1499-1506, 2003.

Received for publication on $25^{\text {th }}$ August 2012 Accepted for publication on $04^{\text {th }}$ June 2013 